doc. dr. sc. Nikola Papac

Sveučilište u Mostaru, Ekonomski fakultet Mostar, Mostar, Bosna i Hercegovina nikola.papac@ef.sum.ba

\title{
KVALITETA KORPORATIVNOG UPRAVLJANJA I LIKVIDNOST POSLOVANJA
}

Primljen: 1. rujna 2019.

Prihvaćen: 15. prosinca 2019.

\author{
Izvorni znanstveni rad
}

\section{Sažetak}

Kvalitetan sustav korporativnog upravljanja temeljni je preduvjet održivog ekonomskog rasta, povećanja efikasnosti gospodarskog sustava te jamac lakšem pristupu vanjskim izvorima kapitala. Razina kvalitete korporativnog upravljanja može se definirati kao stupanj ispunjenja zadanih standarda korporativnog upravljanja definiranih na međunarodnoj i nacionalnoj institucionalnoj razini. Vodeći se dosadašnjim teorijskim i empirijskim spoznajama, Bosna i Hercegovina ima karakteristike zatvorenog sustava korporativnog upravljanja u oba entiteta pa su stoga, kao temelj za razvoj modela mjerenja razine korporativnog upravljanja, odabrani modeli kojima se mjeri korporativno upravljanje u zemljama s tipičnim zatvorenim sustavima korporativnog upravljanja. Mjerenje korporativnog upravljanja daje jasnu sliku snaga $i$ slabosti sustava korporativnog upravljanja u korporacijama u Bosni i Hercegovini te predstavlja temelj dugoročnog održivog i društveno odgovornog rasta i razvoja cjelokupnog gospodarskog sustava u Bosni i Hercegovini. Značajan broj istraživanja pokazuje da korporacije koje ostvaruju više standarde i bolju praksu korporativnog upravljanja imaju i bolje financijske rezultate te samim tim i veću vrijednost na tržištu kapitala. To znači da korporacije s višom razinom korporativnog upravljanja imaju i bolji financijski rezultat poslovanja, lakši pristup financijskom kapitalu te veću vrijednost na tržištu kapitala.

Temeljna svrha istraživanja je utvrditi razinu utjecaja kvalitete korporativnog upravljanja na likvidnost poslovanja, odnosno, sobzirom da se radi o povijesnim podacima, utvrditi jesu li korporacije koje su imale dobro korporativno upravljanje imale $i$ veću likvidnost poslovanja i obratno. Glavni cilj istraživanje je utvrđivanje veze i odnosa između kvalitete korporativnog upravljanja i pokazatelja likvidnosti poslovanja. 
Ključne riječi: korporativno upravljanje, sustav korporativnog upravljanja $u$ entitetima Bosne i Hercegovine, mjerenje kvalitete korporativnog upravljanja, kvaliteta korporativnog upravljanja u Bosni i Hercegovini, indeks RKU

JEL: G28, G34, K20

\section{UVOD}

Korporativno upravljanje definira se kao skup procesa i procedura upravljanja i kontroliranja korporacije. Korporativno upravljanje pokazuje kako su distribuirana prava i odgovornosti između različitih interesno - utjecajnih grupa u korporacijama. Korporativno upravljanje daje odgovor na pitanje tko nadzire korporaciju i kako. Indeksima korporativnog upravljanja se mjeri kvaliteta korporativnog upravljanja na način da se mjeri stopa (postotak) ispunjenosti zadanih kriterija koji su razvrstani u kategorije. Što je god vrijednost konačne ocjene veća (bliže 100\%), kvaliteta korporativnog upravljanja je veća i obrnuto. Značajan broj istraživanja pokazuje da korporacije koje ostvaruju više standarde i bolju praksu korporativnog upravljanja imaju i bolje financijske rezultate te samim tim i veću vrijednost na tržištu kapitala. To znači da korporacije s višom razinom korporativnog upravljanja imaju i bolji financijski rezultat poslovanja, lakši pristup financijskom kapitalu te veću vrijednost na tržištu kapitala. Drugim riječima, viša razina korporativnog upravljanja osigurava lakši pristup kapitalu i manje troškove kapitala $\mathrm{s}$ jedne strane te poboljšanje financijskih performansi poslovanja $\mathrm{s}$ druge strane. Temeljna svrha istraživanja je utvrditi razinu utjecaja korporativnog upravljanja na likvidnost poslovanja, odnosno, s obzirom da se radi o povijesnim podacima, utvrditi jesu li korporacije koje su imale dobro korporativno upravljanje imale i veću likvidnost poslovanja i obratno. Glavni cilj istraživanja je utvrđivanje veze i odnosa između kvalitete korporativnog upravljanja i pokazatelja likvidnosti poslovanja.

\section{MJERENJE KVALITETE KORPORATIVNOG UPRAVLJANJA}

Mjerenje i ocjena razine kvalitete korporativnog upravljanja u jednom gospodarstvu ili korporaciji zahtijeva prije svega razumijevanje cilja i svrhe korporativnog upravljanja. Korporativno upravljanje predstavlja pravni, ekonomski i socijalni fenomen, koji je stvoren prije svega kroz privatnu inicijativu („Cadbury Cometee" i OECD Principi predstavljaju samo institucionalizaciju principa, koji su proizašli iz zdrave poslovne prakse). Osnovni cilj korporativnog upravljanja je maksimizacija efikasnosti poslovanja i smanjenje konflikta interesa između menadžmenta i vlasnika korporacija, kao i smanjenja visine agencijskih troškova 
koji se javljaju kao proizvod odvajanja upravljačke od vlasničke funkcije. Poslovna praksa je pokazala potrebu za institucionalizacijom korporativnog upravljanja unutar korporacija, gdje se njegovom punom implementacijom omogućava efikasno rješavanje problema konflikta interesa vlasnika i menadžmenta korporacije, uz puno poštovanje prava svih „stakeholdera“ od dobavljača, preko radnika, do financijskih institucija i države. Analizirajući dosadašnja istraživanja o značaju korporativnog upravljanja, dokazano je da postoji jasna veza između kvalitete korporativnog upravljanja i vrijednosti dionica, unaprjeđenja i razvoja korporacije te u konačnici zadovoljstva interesno-utjecajnih skupina.

\subsection{Mjerenje kvalitete korporativnog upravljanja u svijetu}

Modeli za mjerenje kvalitete korporativnog upravljanja često se nazivaju i indeksima kvalitete korporativnog upravljanja, a temelje se na ocjeni stupnja ispunjenja zadanih kriterija propisanih supranacionalnim preporukama te nacionalnim zakonskim i podzakonskim aktima. Indeksi su primarno prilagođeni nacionalnom zakonskom i podzakonskom okviru zemlje u kojoj su razvijeni ili se primjenjuju, a njihov oblik i sadržaj ovisi također i od osobina sustava korporativnog upravljanja te iste zemlje. Stoga se može reći da je teško razviti indeks koji bi mogao imati globalnu primjenu, zbog vrlo velikih specifičnosti svakog pojedinog nacionalnog zakonodavnog sustava i gospodarstva. Indeksima korporativnog upravljanja mjeri se kvaliteta korporativnog upravljanja na način da se mjeri stopa (postotak) ispunjenosti zadanih kriterija koji su razvrstani u nekoliko kategorija. ${ }^{1}$

Najveći izazov, ali i jedan od glavnih ciljeva ovog istraživanja bio je odabir adekvatnog indeksa korporativnog upravljanja, koji treba reflektirati kvalitetu prakse korporativnog upravljanja na razini korporacija u $\mathrm{BiH}$. U tom smjeru, imajući u vidu da trenutno ne postoji unificirana formula za izračunavanje kvalitete korporativnog upravljanja, prema uzoru na globalnu praksu, (tablica 1.) kreiran je indeks za ocjenu kvalitete korporativnog upravljanja u BiH te je provedena analiza na najvećim korporacijama na sarajevskoj i banjolučkoj burzi.

Odabrani i promatrani indeksi na temelju kojih je kreiran indeks za ovo istraživanje imaju zadana područja primjene, a razinu korporativnog upravljanja mjere

\footnotetext{
1 Kada govorimo o značaju indeksa, moramo naglasiti da je indeks GMI (Governance Metrics International) davao negativnu ocjenu za Parmalat 2003. godine kada se dogodila velika kriza i propast korporacije. Lawrence Brown i Marcus Taylor s Georgia State University su putem ISS indeksa pokazali vezu između dobre korporativne prakse i performansi korporacije. Putem GMI indeksa također je analizirana i dokazana korelacija između kvalitete korporativnog upravljanja i stope povrata u korporaciji. Ovdje je važno spomenuti i istraživanje Standard \& Poor's indeksa kojim je utvrđena korelacija između kvalitete korporativnog upravljanja i kreditnog rejtinga korporacije. Indeks je davao negativnu ocjenu za Parmalat 2003. godine kada se dogodila velika kriza i propast korporacije.
} 
stopom ispunjenja zadanih kriterija koji su raspoređeni u određene kategorije (tablica 1.). Ovdje se mora naglasiti da područje primjene pojedinog indeksa nije potpuno ograničeno, nego se može prilagođavati s obzirom na osobine sustava korporativnog upravljanja korporacija koje se analiziraju.

Tablica 1. Struktura indeksa za mjerenje korporativnog upravljanja

\begin{tabular}{|c|c|c|c|c|}
\hline Naziv indeksa & Područje primjene & \begin{tabular}{|c|} 
Broj \\
kriterija \\
\end{tabular} & $\begin{array}{l}\text { Broj kat- } \\
\text { egorija }\end{array}$ & Skala ocjene \\
\hline $\begin{array}{c}\text { Corporate Governance } \\
\text { Quotient (CGQ) }\end{array}$ & $\begin{array}{l}\text { S\&P 500, S\&P 400, } \\
\text { S\&P 600, Russell 3000 }\end{array}$ & $\begin{array}{c}63 \\
\text { kriterija }\end{array}$ & 4 kategorije & od 1 do $100 \%$ \\
\hline $\begin{array}{c}\text { S\&P Corporate gover- } \\
\text { nance score ili GAM- } \\
\text { MA score }\end{array}$ & $\begin{array}{c}\text { SAD i V. Britanija } \\
\text { (samo na poziv korpo- } \\
\text { racije) }\end{array}$ & $\begin{array}{c}80 \text { do } \\
100\end{array}$ & 4 kategorije & $\begin{array}{l}\text { od } 1 \text { do } 100 \% \\
(\text { od } 1 \text { do } 10)\end{array}$ \\
\hline GMI rating & $\begin{array}{c}\text { Russell 1000, S\&P } \\
\text { 500, S\&P 400, TSX } \\
\text { 60, Nikkei }\end{array}$ & $\begin{array}{c}450 \\
\text { kriterija }\end{array}$ & $\begin{array}{l}14 \text { kat- } \\
\text { egorija }\end{array}$ & $\begin{array}{l}\text { od } 1 \text { do } 100 \% \\
\text { (od } 1 \text { do } 10)\end{array}$ \\
\hline $\begin{array}{c}\text { DR rating - Deminor } \\
\text { Rating }\end{array}$ & SAD i V. Britanija & $\begin{array}{l}20 \\
\text { složenih } \\
\text { kriterija }\end{array}$ & 4 kategorija & $\begin{array}{c}\begin{array}{c}\text { od DR-1 } \\
\text { (najniža) } \\
\text { do DR-10 }\end{array} \\
\text { (najviša) }=> \\
\text { skala se kreće } \\
\text { po } 1 / 2 \text { vrijed- } \\
\text { nosti }\end{array}$ \\
\hline $\begin{array}{l}\text { Indeks DVFA - Score- } \\
\text { card for German Cor- } \\
\text { porate Governance }\end{array}$ & $\begin{array}{c}\text { Njemačka i druge } \\
\text { zemlje kontinentalne } \\
\text { Europe }\end{array}$ & $\begin{array}{c}47 \\
\text { kriterija }\end{array}$ & 7 kategorija & $\begin{array}{l}\text { od } 1 \text { do } 100 \% \\
\text { (od } 1 \text { do } 8)\end{array}$ \\
\hline $\begin{array}{c}\text { Indeks PFCG - Polish } \\
\text { Forum for Corporate } \\
\text { Governance }\end{array}$ & $\begin{array}{c}\text { Poljska - najviše ocje- } \\
\text { ne OECD-a za razvoj } \\
\begin{array}{c}\text { korporativnog uprav- } \\
\text { ljanja }\end{array} \\
\end{array}$ & $\begin{array}{l}60 \text { kri- } \\
\text { terija }\end{array}$ & 9 kategorija & $\begin{array}{c}\text { od } 1 \text { do } 100 \% \\
\text { (od A do E } \\
\text { - npr. A, A-, } \\
\text { B+, B, B-,..) }\end{array}$ \\
\hline TRIS rating & istočnoazijske burze & $\begin{array}{c}45 \\
\text { kriterija }\end{array}$ & 4 kategorije & $\begin{array}{l}\text { od } 1 \text { do } 100 \% \\
\text { (od } 1 \text { do } 10)\end{array}$ \\
\hline $\begin{array}{l}\text { Brunswick UBS War- } \\
\text { buk }\end{array}$ & moskovska burza & \begin{tabular}{|c}
20 \\
podka- \\
tegorija \\
(složeni \\
kriteriji)
\end{tabular} & $\begin{array}{l}8 \text { glavnih } \\
\text { kategorija }\end{array}$ & $\begin{array}{l}\text { od } 1 \text { za najbo- } \\
\text { lje ocijenjene } \\
\text { tvrtke do } 72 \\
\text { za najlošije }\end{array}$ \\
\hline
\end{tabular}

\section{Izvor: autor}

Svaki od promatranih indeksa mjeri korporativno upravljanje kroz analizu stope ispunjenja zadanih kriterija. Kriteriji su raspoređeni u određene skupine, odnosno kategorije i svaka od zadanih kategorija ima različit statistički značaj (ponder) u ukupnoj ocjeni. Na temelju ovih iskustava definiran je i okvir za razvoj indeksa mjerenja kvalitete korporativnog upravljanja u BiH. Uzor za mjerenje kvalitete korporativnog upravljanja u Bosni i Hercegovini je indeks za mjerenje razine 
korporativnog upravljanja u Njemačkoj naziva DVFA (engl. Scorecard for German Corporate Governance). Posebnost ovog indeksa je u tome da se u svojoj osnovi može prilagoditi $\mathrm{BiH}$, zbog sličnosti u sustavima korporativnog upravljanja, međutim za njegovu potpunu primjenu potreban je odabir kriterija entitetskim zakonima i kodeksima korporativnog upravljanja.

\subsection{Indeks za mjerenje kvalitete korporativnog upravljanja u Bosni i Hercegovini}

Kvaliteta korporativnog upravljanja ocjenjivat će se sa šest kategorija zadanih kriterija. Kategorije ocjene kvalitete korporativnog upravljanja su: ${ }^{2}$

I. Posvećenost principima korporativnog upravljanja i društvena odgovornost

II. Skupština dioničara

III. Nadzorni odbor/neizvršni direktori

IV. Upravni odbor - Uprava

V. Revizija i mehanizmi interne kontrole

VI. Transparentnost poslovanja.

Indeks koji je razvijen za analizu korporativnog upravljanja u BiH nazvan je RKU (skrać. Razina Korporativnog Upravljanja). ${ }^{3}$ Razvijen je i testiran po uzoru na indeks Scorecard for German Corporate Governance, namijenjen za njemačke

2 Broj i vrste kategorija te njihovi ponderi u ukupnoj ocjeni su prilagođeni OECD-ovim principima za korporativno upravljanje iz 2004., zatim, Standardima korporativnog upravljanja u RS-u iz 2011. i Kodeksu korporativnog upravljanja za kompanije uvrštene na tržište Sarajevske burze iz 2009. Model mjerenja i analiza dobivenih rezultata je formiran po uzoru na Scorecard for German Corporate Governance te iskustvima vezanim za indekse kreirane na temelju Sarbanes - Oxley zakona u SAD-u, Combined Code - u Velikoj Britaniji, kao i ostale pokušaje mjerenja kvalitete korporativnog upravljanja. Vrijednost pondera je utvrđena temeljem postojećih iskustava i rezultata istraživanja značaja pojedinih segmenata ocjene za društveno - interesne skupine i njihova utjecaja na ukupnu kvalitetu korporativnog upravljanja.

3 Indeks RKU (prva verzija zvala se BHCoG) razvijen je i testiran u sklopu istraživanja autora za potrebe znanstvenog magistarskog rada na bankama u $\mathrm{BiH}$, a kasnije je revidiran i prilagođen promjenama institucionalnog okvira (druga verzija indeksa je nazvana Indeks RKU). Indeks RKU je razvijen po uzoru na indeks BHCoG kojeg je autor razvio za potrebe analize kvalitete korporativnog upravljanja u bankama u BiH. Indeks BHCoG je kao i indeks RKU razvijen po uzoru na Indeks DVFA - Scorecard for German Corporate Governance, koji je kreiran za potrebe analize korporativnog upravljanja na njemačkim tržištima kapitala. Indeks BHCoG je bio kreiran potpuno po uzoru na indeks DVFA, dok je indeks RKU uzeo u obzir politiku i pravila indeksa DVFA i BHCOG, ali su se za kreiranje kriterija precizno uzeli u obzir kodeksi korporativnog upravljanja Sarajevske i Banjalučke burze vrijednosnih papira.

Prilagođeno prema: Matić, B. i Papac, N.: Measuring the quality of corporate governance in the banking sector of Bosnia and Herzegovina, Economic Research-Ekonomska Istraživanja, Vol. 27, No. 1, 2014., str. 784.-798., Published by Routledge - Taylor \& Francis group, link: http:// dx.doi.org/10.1080/1331677X.2014.974338 
korporacije čijim se dionicama trguje na njemačkim tržištima kapitala. Za potrebe ovog istraživanja prva verzija indeksa je u potpunosti promijenjena i prilagođena kriterijima propisanim u OECD-ovim principima za korporativno upravljanje iz 2004., zatim, Standardima korporativnog upravljanja u RS-u iz 2011. te Kodeksu korporativnog upravljanja za kompanije uvrštene na tržište Sarajevske burze iz 2009. Konačni oblik strukture indeksa je dan u tablici 5.

Tablica 2. Struktura indeksa razine korporativnog upravljanja u $\mathrm{BiH}$ - indeks RKU

\begin{tabular}{|c|c|c|c|}
\hline $\begin{array}{c}\text { Red. } \\
\text { Br. }\end{array}$ & Opis i način ocjenjivanja kriterija & $\begin{array}{c}\text { Broj kriterija } \\
\text { u kategoriji }\end{array}$ & $\begin{array}{c}\text { Udio/ponder u } \\
\text { ukupnoj ocjeni }\end{array}$ \\
\hline I. & $\begin{array}{c}\text { Posvećenost principima korporativnog uprav- } \\
\text { ljanja i društvena odgovornost }\end{array}$ & 7 kriterija & $15 \%$ \\
\hline II. & Skupština dioničara & 9 kriterija & $15 \%$ \\
\hline III. & Nadzorni odbor/neizvršni direktori & 7 kriterija & $10 \%$ \\
\hline IV. & Upravni odbor - Uprava & 9 kriterija & $20 \%$ \\
\hline V. & Revizija i mehanizmi interne kontrole & 5 kriterija & $10 \%$ \\
\hline VI & Transparentnost poslovanja & 9 kriterija & $30 \%$ \\
\hline & UKUPNO & 46 kriterija & $100 \%$ \\
\hline
\end{tabular}

Izvor: autor

Ukupna i konačna ocjena može se iskazati na više načina, prvi je svakako u originalnom obliku i vrijednostima koje su ostvarene analizom, dok je druga mogućnost kroz određeni skup razreda ostvarene vrijednosti (tri, pet, sedam ili deset). Ostvarenim ocjenama će se pridružiti i pripadajući komentari značenja ocjene, kao i određenje faktora koji mogu utjecati na ocjenjivanje.

Konačna ocjena utvrđuje se zbrajanjem vrijednosti koje je svaka pojedinačna kategorija ostvarila u ukupnoj ocjeni, što bi se moglo prikazati obrascem:

\section{"Kategorija 1" + "Kategorija 2" + ... + "Kategorija 6" = ocjena kvalitete korporativnog upravljanja društva prema indeksu $R K U$}

Ocjenjivanje se provodi jednom godišnje i vrijedi za period od jedne poslovne godine (12 mjeseci), odnosno za period između dvije skupštine dioničara. Ocjene se mogu kategorizirati na više načina, najčešće su desetrazinske i petrazinske, međutim to mogu biti i deskriptivne ocjene ostvarene razine korporativnog upravljanja. Struktura razina ocjene i deskripcija je prikazana u tablici 3. 
Tablica 3. Kategorizacija - ocjena razina korporativnog upravljanja

\begin{tabular}{|c|c|c|c|}
\hline $\begin{array}{c}\text { Stupanj ispunjenja } \\
\text { zadanih kriterija }\end{array}$ & $\begin{array}{c}\text { Oznaka ocjene } \\
(1-10)\end{array}$ & $\begin{array}{l}\text { Opis ocjene } \\
\text { (10 razina) }\end{array}$ & Opis ocjene (5 razina) \\
\hline $0-15 \%$ & $\mathrm{~F}$ & izrazito loše & \multirow{2}{*}{$E-1$ loše } \\
\hline $16-25 \%$ & $\mathrm{E}$ & vrlo loše & \\
\hline $26-35 \%$ & $\mathrm{D}$ & loše & \multirow{2}{*}{$\mathrm{D}$ - slabo } \\
\hline $36-45 \%$ & $+\mathrm{D}$ & slabo & \\
\hline $46-55 \%$ & $\mathrm{C}$ & $\begin{array}{c}\text { slabo do sred- } \\
\text { nje }\end{array}$ & \multirow{2}{*}{$\mathrm{C}$ - srednje } \\
\hline $56-65 \%$ & $+\mathrm{C}$ & srednje & \\
\hline $66-75 \%$ & B & $\begin{array}{l}\text { srednje do do- } \\
\text { bro }\end{array}$ & \multirow[t]{2}{*}{ B - dobro } \\
\hline $76-85 \%$ & $+\mathrm{B}$ & dobro & \\
\hline $86-93 \%$ & $\mathrm{~A}$ & vrlo dobro & \multirow{2}{*}{ A - vrlo dobro } \\
\hline $94-100 \%$ & $+\mathrm{A}$ & izrazito dobro & \\
\hline
\end{tabular}

Izvor: autor

Kao što je pokazano u tablici 3., razina korporativnog upravljanja prikazana je stopom ispunjenja zadanih kriterija koji mogu biti kategorizirani u ovome slučaju u pet ili deset razina.

Ocjena korporativnog upravljanja, kao važnog nefinancijskog pokazatelja poslovanja, u svakom slučaju nije zamjena financijskih pokazatelja poslovanja, niti će ikada to biti, ona je prije svega njegova nadopuna s ciljem stvaranja i povećanja povjerenja u promatranu korporaciju.

\section{UZORAK ZA ISTRAŽIVANJE}

U istraživanju se koriste podaci iz 87 korporacija s teritorija Bosne i Hercegovine čijim dionicama se trgovalo na tržištima kapitala u periodu istraživanja, od čega je 49 korporacija smješteno u FBiH, a 38 se nalazi u RS. Prikupljenim podacima izmjeren je koeficijent tekuće likvidnost i koeficijent stabilnosti (zavisna varijabla istraživanja) te kao poseban pokazatelj koristi se koeficijent razine korporativnog upravljanja (RKU), čija se vrijednost može kretati u rasponu od $0-100 \%$, kojim se analizira nezavisna varijabla istraživanja.

Vremenski obuhvat istraživanja ili period za koji je provedeno istraživanje su 2014., 2015. i 2016. godina. Kodeksi korporativnog upravljanja za društva uvrštena na tržištu Sarajevske burze vrijednosnih papira, kao temeljni akti za korporativno upravljanje $\mathrm{u} \mathrm{FBiH}$ usvojeni su 2009. godine, a u aktivnoj su primjeni od 
2010. godine, dok su Standardi upravljanja akcionarskim društvima u Republici Srpskoj u primjeni od 2006. godine, a revidirani su, odnosno usvojeni su Standardi korporativnog upravljanja 2011. godine. Stoga, metodološki gledano, opravdano je promatrati period odabranih godina zbog činjenice da su oba entiteta $\mathrm{u}$ to vrijeme imala u primjeni standarde na temelju kojih mogu prilagoditi vlastite politike upravljanja.

\section{ODNOS KVALITETE KORPORATIVNOG UPRAVLJANJA I LIKVIDNOST POSLOVANJA - RAZVOJ MLM MODELA}

Odnos kvalitete korporativnog upravljanja i likvidnost poslovanja prikazat će se multilevel regresijskim modelom ili MLM modelom. Multilevel ili višerazinski modeli (poznati i kao hijerarhijski linearni modeli, linearni modeli miješanog efekta, miješani modeli, ugniježđeni modeli podataka, modeli slučajnih efekata, modeli slučajnih parametara ili dizajnirani split-plot) statistički su modeli parametara koji se razlikuju u više od jedne razine. Primjer bi mogao biti model uspješnosti učenika koji sadrži mjere za pojedine studente, kao i mjere za učionice u kojima su studenti grupirani.

Ovi se modeli mogu promatrati kao generalizacije linearnih modela (posebno linearne regresije), iako se mogu proširiti i na nelinearne modele.

Modeli na više razina posebno su prikladni za istraživačke nacrte gdje su podaci za sudionike organizirani na više od jedne razine (tj. ugniježđeni podaci). Jedinice analize obično su pojedinci (na nižoj razini) koji se ugnijezde u kontekstualnim/ agregatnim jedinicama (na višoj razini). Kao takvi, višerazinski modeli pružaju alternativnu vrstu analize za univarijantnu ili multivarijantnu analizu ponovljenih mjera. Nadalje, višerazinski modeli mogu se upotrijebiti kao alternativa ANCOVA-i, gdje se rezultati na zavisnoj varijabli prilagođavaju kovarijatima (npr. individualnim razlikama) prije ispitivanja razlika.

Kako je već rečeno u MLM modelu koristi se više testova ili modela kojima se testira postavljena hipoteza te se može zaključiti da ne postoji model ili test za koji možemo kazati da je najbolji za sve situacije. Umjesto toga, svaki model ili test je koristan pod određenim okolnostima. Pored toga korisno je i usporediti sve pokazatelje generirane u MLM modelu i analizirati promjene koje se dešavaju. 


\subsection{Razina kvalitete korporativnog upravljanja u promatranim korporacijama u $\mathrm{BiH}$}

Nezavisna varijabla istraživanja je razina korporativnog upravljanja, mjerena indeksom korporativnog upravljanja koji se sastoji od 46 kriterija raspodijeljenih u 6 kategorija. Vrijednost razine korporativnog upravljanja kreće se u rasponu od 0 do 100, a istraživanje je provedeno na 87 korporacija (49 u FBiH i 38 u RS) u tri vremenska perioda, pa možemo kazati da je promatrana 261 opservacija projekta. U tablici 4. dan je prikaz deskriptivne statistike za neovisnu varijablu RKU.

Tablica 4. Deskriptivna statistika za RKU i cRKU

\begin{tabular}{|c|c|c|}
\hline & RKU & Group Mean Centered RKU (cRKU) \\
\hline $\mathrm{N} \quad$ Valid & 261 & 261 \\
Missing & 0 & 0 \\
Mean & 52.3898 & .0000 \\
Median & 53.7500 & -.1667 \\
Std. Deviation & 13.26799 & 3.28135 \\
Skewness & .027 & 1.029 \\
Kurtosis & -.732 & 11.470 \\
Minimum & 25.60 & -13.57 \\
Maximum & 86.20 & 23.08 \\
\hline
\end{tabular}

Pokazatelji $R K U$ kreću se u rasponu od 25.60 do 86.20 s aritmetičkom sredinom od 52.39. Indeksi simetričnosti i zaobljenosti upućuju na to da distribucija frekvencija varijable $R K U$ ima približno normalan raspored što se može vidjeti i na histogramu. Kontrolom boxplot grafika nije uočen niti jedan outlier (ekstremna vrijednost) za ovu varijablu što se moglo i pretpostaviti na osnovu prikazanog oblika histograma frekvencija (slika 1.).

Slika 1. Distribucija frekvencija vrijednosti nezavisne varijable RKU

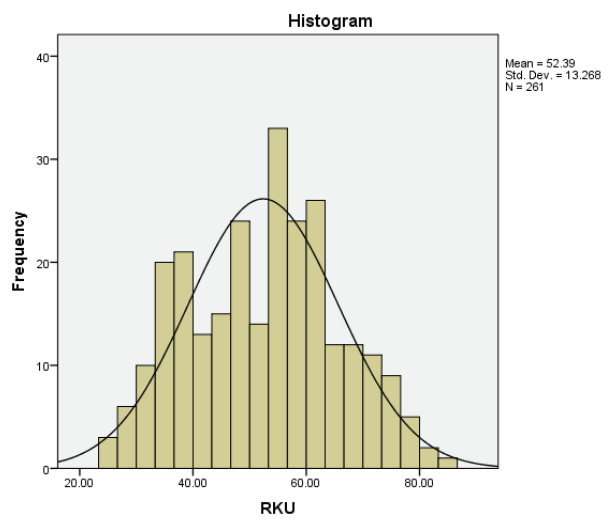

Izvor: autor 
Sljedeći korak analize u MLM-u je centriranje nezavisne metrijske varijable. Centriranje donosi neke prednosti u odnosu na korištenje "sirovih" podataka od kojih se najčešće spominju: smanjenje potencijalnih problema pri estimaciji (razvoju) modela, lakša interpretacija dobivenih parametara i smanjenje problema prouzrokovanih multikolinearnošću (Field, 2009. str. 51. - 120.). U našem slučaju, varijabla $R K U$ nema prirodnu nulu (tj. ne postoji razina korporativnog upravljanja koja bi se mogla ocijeniti nulom). Iz tog razloga, kako bi se olakšala interpretacija dobivenih rezultata, varijabla je centrirana tako da je od svake pojedinačne opservacije oduzeta aritmetička sredina grupe, odnosno korporacije kojoj ta opservacija pripada $\left(\mathrm{X}_{i}-\overline{\boldsymbol{x}}_{j}\right)$. Rezultat je varijabla $c R K U$ kod koje se aritmetička sredina nalazi na nuli. Riječ je o tzv. centriranju varijable u odnosu na aritmetičku sredinu grupe (engl. Group Mean Centering). Drugi način na koji se moglo centrirati $R K U$ je taj da se od vrijednosti svake pojedinačne opservacije date varijable oduzme aritmetička sredina ( $\mathrm{tj}$. Xi -52.3898). U tom slučaju govorili bi o centriranju oko općeg prosjeka (engl. Grand Mean Centering).

Centriranje odabranih varijabli prije modeliranja je standardni postupak i o njegovim efektima su pisali mnogi autori (Kreft, Leeuw i Aiken, 1994., str. 121. - 138.), (Hofmann i Gavin, 1998., str. 623. - 640.), (Kreft i Leeuw, 1998., str. 106. - 114.), (Enders i Tofighi, 2007. str. 121. - 138.). Najveća dilema u vezi centriranja ogleda se u tome, koje od dvije moguće metode centriranja koristiti i kada: Grand Mean Centering ili Group Mean Centering. Izbor ovisi prvenstveno o vrsti istraživačkog pitanja. Enders i Tofighi (2007.) daju generalne smjernice o izboru metode centriranja u kojima navode da je za modele u kojima se nastoji ispitati diferencijalni utjecaj varijable na dva nivoa u hijerarhiji (u našem slučaju su to opservacije unutar korporacija - razina 1 i razlike između korporacija - razina 2), podjednako dobro mogu koristiti obje metode centriranja podataka jer daju ekvivalentne procijenjene parametre. Štoviše, Kreft i Leeuw (1998., str. 109.) navode da su u istraživanjima s ponovljenim mjerenjima (engl. repeated measures), modeli u kojima je korišten bilo koji od ova dva oblika centriranja ekvivalentni u pogledu svih procijenjenih parametara. Ovdje je potrebno napomenuti da ekvivalentni parametri ne znače isto što i identični parametri. Naime, u modelu gdje je korišten Group Mean Centering, procijenjeni parametar, kojim se mjeri utjecaj varijable na višem nivou (u našem slučaju je to prosjek grupe - meanRKU), u sebi će inkorporirati isključivo utjecaj na zavisnu varijablu između grupa. Ipak, diferencijalna razlika se može dobiti prostim izračunavanjem razlike između vrijednosti parametra na razini $1(c R K U)$ i parametra na razini 2 (meanRKU). Ova razlika će biti identična procijenjenom diferencijalnom efektu parametra za razinu 2 (meanRKU) u modelu gdje je korišten Grand Mean Centering. Stoga se kaže da su parametri ekvivalentni (Enders i Tofighi, 2007. str. 121. - 138.). 
Newsom (2013.) u svojim bilješkama navodi da je Group Mean Centering preferirana metoda za situacije kada nas primarno zanima utjecaj jedne varijable na dvije razine s obzirom da daje nešto konkretniju interpretaciju procijenjenog efekta date varijable za razinu 2. Također, provođenjem Group Mean centriranja u potpunosti se eliminira korelacija između level 1 i level 2 prediktora. Zbog navedenog, mi smo se odlučili za Group Mean centriranje.

I varijabla meanRKU je centrirana. Dakle, aritmetička sredina za ovu varijablu iznosi 0 i odgovara razini prosječnog korporativnog upravljanja za 87 korporacija iz uzorka. Za varijable na razini 2 uvijek je riječ o centriranju oko općeg prosjeka (Enders i Tofighi, 2007. str. 121. - 138.).

\subsection{Razina tekuće likvidnosti u promatranim korporacijama u BiH}

Prvi korak je prikaz deskriptivne statistike, koji je za ovu varijablu dan u tablici 5.

Tablica 5. Deskriptivna statistika za koeficijent tekuće likvidnosti LTE

Izvor: autor

\begin{tabular}{|l|l|l|}
\hline \multirow{N}{N}{} & Valid & 261 \\
\cline { 2 - 3 } & Missing & 0 \\
\hline Mean & 3.7157 \\
Median & 1.6527 \\
Std. Deviation & 5.41943 \\
Skewness & 3.530 \\
Std. Error of Skewness & .151 \\
Kurtosis & 16.736 \\
Std. Error of Kurtosis & .300 \\
Minimum & .07 \\
Maximum & 42.48 \\
\hline
\end{tabular}

Može se primijetiti da se vrijednost koeficijenta tekuće likvidnosti kreće u rasponu od 0.07 do 42.48. Prosječna vrijednost je 3.72 dok je medijalna vrijednost 1.65. Ovakva razlika između medijalne i prosječne vrijednosti upućuje na zaključak da je distribucija opserviranih vrijednosti nagnuta na lijevu stranu. Ovo nam potvrđuje indeks simetričnosti (engl. skewness) i indeks zaobljenosti (engl. kurtosis). Normalna distribucija bi trebala imati oba indeksa što bliža vrijednosti 0. Što je indeks simetričnosti više negativan, distribucija je više zakrivljena na desnu stranu. Suprotno tome, što je indeks simetričnosti dalje od nule u pozitivnom smjeru, distribucija je više zakrivljena u lijevu stranu. Isto tako, ako je indeks spljoštenosti dalje od nule u negativnom smjeru distribucija frekvencija ima spljošteniji oblik u odnosu na normalnu distribuciju, dok pozitivne vrijednosti ovog indeksa ukazuju na distribuciju frekvencija više koncentriranu oko aritmetičke sredine. 


\section{Odnos razine korporativnog upravljanja i likvidnosti poslovanja promatranih korporacija}

Za testiranje ovog odnosa korištena su dva pokazatelja likvidnosti: koeficijent tekuće likvidnosti (LTE) i koeficijent financijske stabilnosti (LFS). U prvom koraku testiranja pomoćne hipoteze prikazan je razvoj modela utjecaja RKU na koeficijent tekuće likvidnosti LTE (tablica 6.).

Tablica 6. Razvoj MLM modela utjecaja RKU na koeficijent tekuće likvidnosti (LTE_ln)

\begin{tabular}{|c|c|c|c|c|}
\hline struktura modela & model & \multicolumn{2}{|c|}{ Coef. } & $\begin{array}{c}-\log \\
\text { likelihood }\end{array}$ \\
\hline \multirow{2}{*}{ LTE_ln $\ln _{i j}($ cons $)$} & M1 & cons & $\left(0.646^{* * *}\right)$ & -204.68 \\
\hline & M1s & cons & $\left(0.641^{* * *}\right)$ & -178.83 \\
\hline \multirow{2}{*}{ LTE_ln $\ln _{i j}(c R K U$, mainRKU) } & M2 & $\begin{array}{l}c R K U \\
\text { mainRKU }\end{array}$ & $\begin{array}{l}\left(0.012^{*}\right) \\
\left(0.046^{* * *}\right)\end{array}$ & -187.76 \\
\hline & M2s & $\begin{array}{l}c R K U \\
\operatorname{mainRKU}\end{array}$ & $\begin{array}{l}(0.009) \\
\left(0.051^{* * *}\right)\end{array}$ & -162.66 \\
\hline \multirow{2}{*}{$\begin{array}{c}\mathrm{LTE} \ln _{i j}(\mathrm{time}, c R K U, \operatorname{main} R- \\
K U)\end{array}$} & M3 & $\begin{array}{l}\text { time } \\
c R K U \\
\text { mainRKU }\end{array}$ & $\begin{array}{l}(-0.023) \\
\left(0.014^{* *}\right) \\
\left(0.046^{* * *}\right)\end{array}$ & -187.23 \\
\hline & M3s & $\begin{array}{l}\text { time } \\
c R K U \\
\text { mainRKU }\end{array}$ & $\begin{array}{l}(-0.027) \\
(0.013) \\
\left(0.051^{* * *}\right) \\
\end{array}$ & -162.04 \\
\hline \multirow{2}{*}{$\begin{array}{c}\mathrm{LTE} \ln _{i j}(\text { time, } c R K U, \text { mainR- } \\
K U \text {, entitet })\end{array}$} & M4 & $\begin{array}{l}\text { time } \\
\text { cRKU } \\
\text { mainRKU } \\
\text { entitet }\end{array}$ & $\begin{array}{l}(-0.023) \\
\left(0.014^{* *}\right) \\
\left(0.046^{* * *}\right) \\
(-0.056)\end{array}$ & -187.20 \\
\hline & M4s & $\begin{array}{l}\text { time } \\
c R K U \\
\text { mainRKU } \\
\text { entitet }\end{array}$ & $\begin{array}{l}(-0.027) \\
(0.013) \\
\left(0.050^{* * *}\right) \\
(0.065)\end{array}$ & -161.99 \\
\hline \multirow{2}{*}{$\begin{array}{c}\text { LTE_ln } \ln _{i j} \text { (time, cRKU, meanR- } \\
K U \text {, slope-time) }\end{array}$} & M5 & $\begin{array}{l}\text { time } \\
c R K U \\
\text { mainRKU }\end{array}$ & $\begin{array}{l}(-0.020) \\
\left(0.013^{*}\right) \\
\left(0.043^{* * *}\right)\end{array}$ & -183.34 \\
\hline & M5s & $\begin{array}{l}\text { time } \\
c R K U \\
\text { mainRKU }\end{array}$ & $\begin{array}{l}(-0.022) \\
(0.010) \\
\left(0.049^{* * *}\right)\end{array}$ & -158.53 \\
\hline \multirow{2}{*}{$\begin{array}{c}\mathrm{LTE} \ln _{i j}(\text { time } c R K U \text { meanR- } \\
K U \text { slope-cRKU) }\end{array}$} & M6 & $\begin{array}{l}\text { time } \\
c R K U \\
\text { mainRKU }\end{array}$ & $\begin{array}{l}(-0.021) \\
\left(0.017^{*}\right) \\
\left(0.045^{* * *}\right)\end{array}$ & -186.68 \\
\hline & M6s & $\begin{array}{l}\text { time } \\
c R K U \\
\text { mainRKU }\end{array}$ & $\begin{array}{l}(-0.028) \\
\left(0.020^{*}\right) \\
\left(0.049^{* * *}\right)\end{array}$ & -159.55 \\
\hline
\end{tabular}

Standard errors in parentheses: ${ }^{*} p<0.05,{ }^{* *} p<0.01,{ }^{* * *} p<0.001$

Izvor: autor 
Koeficijent tekuće likvidnosti (LTE) je omjer između kratkoročne imovine i kratkoročnih obveza korporacije i poželjno je da je njegova vrijednost što veća (idealno je da je veća od 2). Za testiranje prikazanog odnosa u prvom koraku bilo je potrebno transformirati podatke za koeficijent tekuće likvidnosti LTE zbog odstupanja distribucije frekvencija varijable od normalne distribucije, a transformirani su primjenom logaritamske baze $e($ tzv. prirodni logaritam $-\ln )$ pa je ta transformirana logaritmirana varijabla označena kao $L T E \_l n$. U ocjeni utjecaja RKU na $L T E \_l n$ razvijeno je šest modela za cijeli uzorak i šest modela za skraćeni uzorak. U tablici 6. prikazana je vrijednost LL koeficijenta, odnosno informativnog kriterija koji pokazuje reprezentativnost modela. ${ }^{4}$

Za konačnu ocjenu utjecaja RKU na LTE_ln uzet je model M2, gdje su vrijednosti koeficijenata $c R K U$ i meanRKU signifikantni i pokazuju da porast $c R K U$ za $1 \%$ doprinosi porastu koeficijenta LTE unutar korporacija za 1,2\%, a porast meanRKU uzrokuje porast koeficijenta LTE za 4,6\% između korporacija.

Model M2 odabran je jer dodavanjem drugih nezavisnih varijabli (time, entitet, nagiba prema time $i$ nagiba prema cRKU) koje nisu od interesa za testiranje hipoteze u nekim je situacijama povećalo reprezentativnost modela (M3, M4 i M5), ali dodane varijable su ostale nesignifikantne, a nije se značajno promijenila ni vrijednost koeficijenata od interesa za hipotezu ( $c R K U$ i meanRKU). Stoga možemo zaključiti da je za objašnjenje utjecaja RKU na LTE odabran model M2 jer daljnji razvoj modela (usložnjavanje modela i skraćenje uzorka) nije doprinijelo nikakvim značajnijim promjenama fiksnih koeficijenata, niti je bilo ikakvih drugih bitnih promjena i unaprjeđenja u odnosu na model M2. Može se konstatirati da mala poboljšanja reprezentativnosti nisu bila razlog da se odabere složeniji model te je za konačnu ocjenu uzet model M2. Usputno se može kazati da je u usporedbi i testiranju LL, model M2 pokazivao najveću razinu statističke značajnosti $(\mathrm{p}<0.000)$.

U drugom koraku testiranja prikazan je razvoj modela utjecaja RKU na koeficijent financijske stabilnosti LFS (tabela 7). Koeficijent financijske stabilnosti predstavlja odnos vrijednosti dugotrajne imovine i kapitala uvećanog za dugoročne obveze, a poželjno je da mu je vrijednost što bliže 0 (manje od 1$)$.

Za testiranje utjecaja RKU na LFS u prvom koraku bilo je potrebno transformirati podatke za koeficijent financijske stabilnosti LFS, a transformirani su također primjenom logaritamske baze $e$, pa je ta transformirana logaritmirana varijabla označena kao $L F S \_$In. Za ocjenu utjecaja $R K U$ na $L F S \_$In razvijeno je šest

$4 \quad$ Log likelihood je statistički test koji se koristi za usporedbu dva ili više modela, od kojih je jedan osnovni, a drugi je izvedeni. Što god je vrijednost ovog pokazatelja bliže 0 , model ima veću reprezentativnost. Isto vrijedi i za BIC i AIC testove za usporedbu modela. 
modela za cijeli uzorak i šest modela za skraćeni uzorak. U tablici 7. je prikazana i vrijednost LL koeficijenta, odnosno informativnog kriterija koji pokazuje reprezentativnost modela.

Tablica 7. Razvoj MLM modela utjecaja RKU na koeficijent financijske stabilnosti (LFS_ln)

\begin{tabular}{|c|c|c|c|c|}
\hline struktura modela & model & \multicolumn{2}{|c|}{ Coef. } & -log likelihood \\
\hline \multirow{2}{*}{ LFS_ln $\ln _{i j}($ cons $)$} & M1 & cons & $(-0.089)$ & -113.32 \\
\hline & M1s & cons & $\left(-0.124^{* *}\right)$ & 17.00 \\
\hline \multirow{2}{*}{$\begin{array}{l}\text { LFS_ln } \ln _{i j}(c R K U, \text { mainR- } \\
K U)\end{array}$} & M2 & $\begin{array}{l}c R K U \\
\operatorname{main} R K U\end{array}$ & $\begin{array}{l}(0.004) \\
\left(-0.009^{*}\right)\end{array}$ & -110.07 \\
\hline & M2s & $\begin{array}{l}c R K U \\
\operatorname{main} R K U\end{array}$ & $\begin{array}{l}(-0.003) \\
\left(-0.009^{* *}\right)\end{array}$ & 21.85 \\
\hline \multirow{2}{*}{$\begin{array}{l}\text { LFS } \ln _{i j} \text { (time, } c R K U, m a- \\
i n R K U)\end{array}$} & M3 & $\begin{array}{l}\text { time } \\
c R K U \\
\operatorname{mainRKU}\end{array}$ & $\begin{array}{l}(0.000) \\
(0.004) \\
\left(-0.009^{*}\right)\end{array}$ & -110.07 \\
\hline & M3s & $\begin{array}{l}\text { time } \\
c R K U \\
\text { mainRKU }\end{array}$ & $\begin{array}{l}(0.000) \\
(-0.003) \\
\left(-0.009^{* *}\right)\end{array}$ & 21.85 \\
\hline \multirow{2}{*}{$\begin{array}{l}\text { LFS } \ln _{i j} \text { (time, } c R K U, \text { ma- } \\
\text { inRKU, entitet) }\end{array}$} & M4 & $\begin{array}{l}\text { time } \\
c R K U \\
\text { mainRKU } \\
\text { entitet }\end{array}$ & $\begin{array}{l}(0.000) \\
(0.004) \\
\left(-0.010^{* *}\right) \\
(0.150)\end{array}$ & -108.87 \\
\hline & M4s & $\begin{array}{l}\text { time } \\
\text { cRKU } \\
\text { mainRKU } \\
\text { entitet }\end{array}$ & $\begin{array}{l}(0.000) \\
(-0.003) \\
\left(-0.009^{* *}\right) \\
(0.063)\end{array}$ & 22.19 \\
\hline \multirow{2}{*}{$\begin{array}{l}\text { LFS } \ln _{i j} \text { (time, cRKU, me- } \\
\text { anRK } U \text {, slope-time) }\end{array}$} & M5 & $\begin{array}{l}\text { time } \\
c R K U \\
\operatorname{mainRKU}\end{array}$ & $\begin{array}{l}\text { (N/A) } \\
\text { (N/A) } \\
\text { (N/A) }\end{array}$ & N/A \\
\hline & M5s & $\begin{array}{l}\text { time } \\
c R K U \\
\operatorname{mainRKU}\end{array}$ & $\begin{array}{l}(-0.002) \\
(-0.002) \\
\left(-0.009^{* *}\right)\end{array}$ & 37.86 \\
\hline \multirow{2}{*}{ 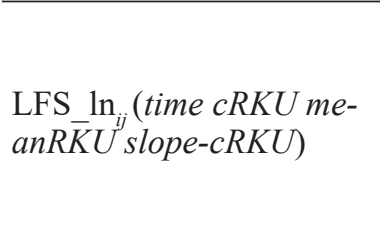 } & M6 & $\begin{array}{l}\text { time } \\
c R K U \\
\text { mainRKU }\end{array}$ & $\begin{array}{l}(0.009) \\
(-0.006) \\
\left(-0.006^{*}\right)\end{array}$ & -49.40 \\
\hline & M6s & $\begin{array}{l}\text { time } \\
c R K U \\
\text { mainRKU }\end{array}$ & $\begin{array}{l}(0.000) \\
(-0.006) \\
\left(-0.009^{* *}\right)\end{array}$ & 27.59 \\
\hline
\end{tabular}

${ }^{*} p<0.05,{ }^{* *} p<0.01,{ }^{* * *} p<0.001$

Izvor: autor

Za ocjenu utjecaja $R K U$ na $L F S$ In odabran je model M2s, gdje su vrijednosti koeficijenata $c R K U$ i meanRKU negativne, a vrijednost koeficijenta za $c R K U$ nije 
signifikantna, dok je vrijednost koeficijenta za meanRKU signifikantna i negativna te govori da porast meanRKU za $1 \%$ uzrokuje pad vrijednosti koeficijenta LFS za 0,9\% unutar korporacija.

Dodavanjem drugih nezavisnih varijabli u model (time i entitet, nagiba prema time $i$ nagiba prema cRKU) koje nisu od interesa za testiranje hipoteze, samo se modelu M4 povećala reprezentativnost modela (LL informativni kriterij), ali dodane varijable (time i entitet) su ostale nesignifikantne te se nije značajno promijenila vrijednost koeficijenata od interesa za hipotezu ( $c R K U$ i meanRKU). Vrijednost koeficijenta $c R K U$ je u svim modelima za cijeli uzorak nesignifikantna i svugdje ima negativnu vrijednost, osim u modelu M4. Što se tiče skraćenog uzorka, najreprezentativniji je model M2s, koji je ujedno i najreprezentativniji od svih modela, gdje je vrijednost koeficijenta meanRKU gotovo identična kao i kod $\mathrm{M} 2$, dok je vrijednost koeficijenta $c R K U$ i dalje ostala nesignifikantna.

Temeljem svega navedenog možemo zaključiti da je za ocjenu utjecaja korporativnog upravljanja na likvidnosti poslovanja odabran model druge razine (M2 i M2s) i da su utvrđeni sljedeći zaključci:

a) kod ocjene utjecaja RKU na LTE_ln vrijednosti koeficijenata $c R K U$ i $m e$ anRKU su signifikantne i pokazuju da porast $c R K U$ za $1 \%$ doprinosi porastu koeficijenta LTE unutar korporacija za 1,2\%, a porast meanRKU uzrokuje porast koeficijenta LTE za 4,6\% između korporacija;

b) kod ocjene utjecaja $R K U$ na $L F S \_l n$ vrijednosti koeficijenata $c R K U$ i meanRKU su negativne, ali vrijednost koeficijenta za $c R K U$ nije nikada signifikantna, dok je vrijednost koeficijenta za meanRKU gotovo uvijek signifikantna i model M2s pokazuje da porast meanRKU za $1 \%$ uzrokuje pad koeficijenta LFS za 0,9\% unutar korporacija.

Može se zaključiti da porast razine korporativnog upravljanja (RKU) utječe na porast razine tekuće likvidnost LTE (idealno da je vrijednost što veća) i unutar i između korporacija, dok porast razine korporativnog upravljanja (RKU) uzrokuje pad vrijednosti koeficijenta financijske stabilnost LFS (idealno da je vrijednost što bliže 0) unutar korporacija.

Temeljem svega navedenog može se zaključiti da viša razina korporativnog upravljanja pozitivno utječe na likvidnost poslovanja, a za njeno dokazivanje razvijen je složeni MLM model te je od ukupno dvanaest razvijenih modela (̌̌est za puni i šest za skraćeni uzorak) odabran model druge razine (M2 i M2s), kojeg možemo predstaviti matematički,

$$
\text { likvidnost_poslovanja }=\beta_{0 j}+\beta_{1} c R K U_{j}+\beta_{2} \text { meanRKU } U_{j}+e_{j} \text {, }
$$


i zaključiti da se zapravo radi o istom modelu druge razine. Međutim, kod prvog slučaja utjecaja RKU na $L T E \_$ln najreprezentativniji je bio model primijenjen na cijelom uzorku, a u drugom slučaju utjecaja RKU na $L F S \_$In najreprezentativniji je bio isti model, ali primijenjen na skraćenom uzorku. Temeljem svega navedenog može se zaključiti da porast korporativnog upravljanja utječe na porast razine likvidnosti poslovanja.

\section{ZAKLJUČAK}

Viša razina kvalitete korporativnog upravljanja (RKU) utječe na porast razine tekuće likvidnost (idealno da je vrijednost što veća) i unutar i između korporacija, dok porast razine korporativnog upravljanja (RKU) uzrokuje pad vrijednosti koeficijenta financijske stabilnosti LFS (idealno da je vrijednost što bliže 0) unutar korporacija. Glavni cilj istraživanje je utvrđivanje veze i odnosa između kvalitete korporativnog upravljanja i pokazatelja likvidnosti poslovanja.

Sintezom empirijskih rezultata istraživanja provedenih na 87 korporacije u BiH, došlo se do zaključka da korporativno upravljanje utječe na likvidnost poslovanja, odnosno, empirijsko istraživanje je potvrdilo statistički značajnu vezu između razine korporativnog upravljanje i pokazatelja likvidnost. Uzorak istraživanja je činilo 87 korporacija čijim dionicama se trgovalo na entitetskim burzama u periodima istraživanja u Bosni i Hercegovini, od čega je 49 bilo iz entiteta Federacije Bosne i Hercegovine, a 38 iz entiteta Republike Srpske. Svi prikupljeni i mjereni podaci odnose se na period 2014., 2015. i 2016. godine.

Uzimajući u obzir sve navedeno, zaključak je da korporativno upravljanje utječe na financijsku uspješnost poslovanja korporacija u $\mathrm{BiH}$, a za istraživanje je kreiran i primjeren indeks RKU s jedne strane te je odabrana i obrazložena primjena pokazatelja financijske uspješnosti s druge strane. Smjer i intenzitet odnosa između zavisne i nezavisne varijable testiran je statističkim modelom MLM, gdje je zaključeno da su korporacije koje su primjenjivale više standarde korporativnog upravljanja ostvarivale i bolje pokazatelje financijske uspješnosti poslovanja. Cilj istraživanja je bio prikazati utjecaj nefinancijskih pokazatelja (korporativno upravljanje) na likvidnost poslovanja s ciljem pronalaženja modela koji bi obuhvaćao i jednu i drugu skupinu pokazatelja te davao što potpuniju, pouzdaniju i objektivniju sliku o poslovanju korporacije. Ovdje se posebno treba naglasiti polazna pretpostavka ovog istraživanja koja glasi da nefinancijski pokazatelji poslovanja nisu i ne mogu biti nikako zamjena za financijske, oni su zapravo nadopuna financijskim pokazateljima poslovanja pa njihovo integriranje ima za cilj unaprijediti i povećati povjerenje u objektivnost svih korporativnih izvješća. Temeljni empirijski doprinosi mogu se sažeti u činjenice da je istraživanjem 
izmjerena, kvantificirana kvaliteta korporativnog upravljanja (indeks RKU) i likvidnost poslovanja te da je provedena analiza ovog odnosa sukladno postavljenim ciljevima. Odnos između dvije promatrane varijable je proveden statističkim MLM modelom, čija je temeljna prednost što promatra složenost društvenih odnosa u kojima posluju korporacije, mjeri utjecaj drugih nezavisnih varijabli koje nisu od interesa za postavljeni odnos, ali utječu na promatrani odnos te se njime može kreirati stohastički član $e_{i}$ s kompleksnom strukturom.

\section{LITERATURA}

1. Ashbaugh, H., Collins, D. W. i LaFond, R. (2006.), Corporate Governance and the Cost of Equity Capital,. Paper presented at Emory, University of Iowa

2. Babić, M., Simić, M., Šunje, A. i Puljić, M. (2008.), Korporativno upravljanje - principi i mehanizmi. Sarajevo: Revicon

3. Bai, C., Liu, Q., Lu, J., Song, F. i Zhang, J. (2003.), Corporate Governance and Market Valuation in China. William Davidson Working Paper Number 564, Michigan

4. Bubbico, R., Giorgino, M. i Monda, B. (2012.), The impact of Corporate Governance on the market value of financial institutions: empirical evidences from Italy. MPRA Paper No. 45419, University Library of Munich .

5. Čengić, D. (2001.), Vlasnici, menadžeri i kontrola poduzeća - prilozi analizi korporacijskog upravljanja u Hrvatskoj. Zagreb: Institu Ivo Pilar.

6. Deminor Rating, European Report 2000, The Deminor Corporate Governance Rating Service (ed.), preuzeto sa http://deminor-rating.com, lipanj 2013.

7. DVFA, Scorecard for German Corporate Governance (Version March 2002), Dreieich: German Society of Financial Analysts, preuzeto sa http://www. dvfa.de, siječanj 2013.

8. Enders, C. i Davood, T. (n.d.). Centering Predictor Variables in Cross-Sectional Multilevel Models:A New Look at an Old Issue. Psychological Methods, Vol. 12, No. 2, str. 121-138.

9. Gruszczynski, M. (2006.), Corporate governance and financial performance of companies in Poland. International Advances in Economic Research, Vol. 12 No. 2.

10. Gruszczynski, M. (2007.), Corporate governance and financial performance of companies in Poland, 63rd International Atlantic Economic Conference, Madrid, dostupno na: http://www.sgh.waw.pl/instytuty/zes/wp/, siječanj 2013. 
11. Gruszczynski, M. (2010.), Investor protection and disclosure. Quantitative evidence, Warsaw School of Economics Department of Applied Econometrics, dostupno na: http://www.sgh.waw.pl/instytuty/zes/wp/, siječanj 2013.

12. Haque, F., Arun, T. i Kirkpatrick, C. (2008.), Corporate governance and capital markets: a conceptual framework, Corporate Ownership and Control. Preuzeto sa: http://www.virtusinterpress.org/additional_files/journ_coc/fulltext-papers-open-access/Paper012.pdf, str. 264-277.

13. Matić,B.i Papac, N.: Measuring the quality of corporate governance in the banking sector of Bosnia and Herzegovina, Economic Research-Ekonomska Istraživanja, Vol. 27, No. 1, 2014., str. 784.-798., Published by Routledge - Taylor \& Francis group, link: http://dx.doi.org/10.1080/1331677X.2014.974338

14. Monda, B. i Giorgino, M. (2013.). Corporate Governance and Shareholder Value in Listed Firms: An Empirical Analysis in Five Countries (France, Italy, Japan, UK, USA). MPRA Paper No. 45422, Munich .

15. Nieuwenhuis, R., Grotenhuis, M. i Pelzer, B. (2006.), Influential Cases in Multilevel Modeling: A Methodological Comment. American Sociological Review, 75(1), dostupno na: http://www.asanet.org/images/journals/docs/ pdf/asr/Feb10ASRFeature.pdf, str. 173-178.

16. Papac, N. (2013.), Measuring the quality and characteristics of system od corporate governance in Bosnia and Herzegovina. Zbornik radova - Jurnal of economy and business, Ekonomskog fakulteta Sveučilišta u Mostaru XIX., Mostar.

17. Selvaggi, M. i Upton, J. (2008.), Governance and performance in corporate Britain. ABI Research and Investment Affairs Departments London.

18. Singer, J. (1998.), Using SAS PROC MIXED to fit multilevel models, hierarchical models and individual growth models. Journal of Educational and Behavioral Statistics, Vol. 24, No. 4, str. 323-355.

19. Standard\&Poor's. (2008.), GAMMA - Governance, Management, Accountability Metrics and Analysis (criteria and definitions), S\&P, New York

20. Tabachnick, B. G. i Fidell, F. (2012.), Using Multivariate Statistics, 5th Edition London.

21. Tipurić, D. (. (2008.), Korporativno upravljanje. Zagreb: Sinergija.

22. Tipurić, D. i Lovrinčević, M. (2011.), Stakeholderska orijentacija poduzeća i korporativno upravljanje. Sarajevo Business and Economics Review, 31 (2011), 1, Sarajevo, str. $281-300$.

23. WB/IFC. (2013.), Global Competitiveness Report 2012-2013. WB/IFC 2012 Doing Business 2013 i WEF 2012, preuzeto sa: http://www.doingbusiness. org/data/exploretopics/protecting-investors . 
24. West, B., Welch, K. i Galecki, A. (2007.), Linear Mixed Models: A Practical Guide Using Statistical Software. Champan \& Hall/CRC London.

25. Žager, K., Mamić, I., Sever, S. i Žager, L. (2008.), Analiza financijskih izvještaja. Zagreb: Masmedia.

Nikola Papac, PhD

University of Mostar, Faculty of Economics, Mostar, B\&H

nikola.papac@ef.sum.ba

\title{
QUALITY OF CORPORATE GOVERNANCE AND BUSINESS LIQUDITY
}

Recived: September 1, 2019

Accepted: December 15, 2019

\section{Original scientific paper}

\begin{abstract}
An efficient corporate governance system is a basic prerequisite for sustainable economic growth, increase of economic system efficiency and a guarantee for easier approach to external sources of capital. The quality level of corporate governance can be defined as level of fullfilment of corporate governance set standards defined at international and national institutional level. Based on existing theoretical and empirical findings, Bosnia and Herzegovina has characteristics of a closed corporate governance system in its both entities. Therefore models for measuring corporate governance in countries with typically closed corporate governance systems are selected as basis for development of models for measuring level of corporative governance. Corporate governance meaurement gives clear picture of strenghts and weaknesses of corporate governance system in corporations in Bosnia and Herzegovina. It also represents basis for long-term sustainable and socially responsible growth and development of entire economic system in Bosnia and Herzegovina. A significant number of researches show that corporations with higher standards and better practice in corporate governance have also better financial results and therefore higher value in the capital market. This means that corporations with higher level of corporate governance have
\end{abstract}


also better financial results, eaasier approach to financial capital and higher value in the capital market.

The main purpose of this research is to determine the impact level of quality of corporate governance on business liquidity, that is, since it is about historical data, to determine whether corporations with good corporate governance have higher business liquidity and vice versa. The main objective of the research is to determine relations and between quality of corporate governance and business liquidity indicators.

Keywords: corporate governance, corporate governance in $B \& H$, measure of corporate governance quality, quality of corporate governance in $B \& H, R K U$ index

JEL: G28, G34, K20 